\title{
A Rare Case of Zosteriform Cutaneous Metastasis from Breast Cancer
}

\section{Meme Kanserli Bir Olguda Zosteriform Deri Metastazı}

\author{
Filiz Topaloğlu Demir, Kenyul Salaeva, ilknur Kıvanç Altunay, Özben Yalçın* \\ Şişli Training and Research Hospital, Clinic of Dermatology, Istanbul, Turkey \\ *Şişli Training and Research Hospital, Clinic of Pathology, istanbul, Turkey
}

\begin{abstract}
Breast cancer is the most common cancer among women and the second leading cause of cancer deaths, after lung cancer. Cutaneous breast cancer metastases often develop as direct involvement and local spread and often manifest as solid painless nodules in the anterior chest wall. Internal malignant skin metastases rarely present like soft nodules, telangiectasia-like lesions, neoplastic alopecia, erysipeloides carcinoma, erythema annulare-like, herpetiformis or zosteriform, targetlike, pyodermic and morphea-like lesions. In this article, we present a 49-year-old female patient describing a sensation of burning pain with erythematous papules and plaques in a zosteriform distribution. The diagnosis of zosteriform cutaneous metastases from a breast cancer was made. Majority of these cases may be misdiagnosed as herpes zoster infection and can be treated with antiviral drugs. Therefore, cutaneous metastases should be kept in mind in the differential diagnosis of lesions in zosteriform distribution.
\end{abstract}

Keywords: Cutaneous metastasis, zosteriform cutaneous metastasis, breast cancer

\begin{abstract}
Meme kanseri kadınlar arasında en sık görülen kanserdir ve akciğer kanserinden sonra, kansere bağlı ölümlerin en sık sebebidir. Meme kanserinin deri metastazı genellikle direkt invazyon ve lokal yayılma şeklinde gelişir ve sıklıkla gögüs ön duvarında solid ve ağrısız nodüller şeklinde ortaya çıkar. İnternal malignitelerin deri metastazları nadiren yumuşak nodüller, telenjiektazi benzeri lezyonlar, neoplastik alopesi, karsinoma erizipeloides, eritema anüler benzeri, herpetiform veya zosteriform, target benzeri, piyodermatik ve morfea benzeri lezyonlar ile prezente olabilmektedir. Bu makalede zosteriform dizilimli, deriden kabarık, eritematöz papül ve plaklarla polikliniğimize başvuran, lezyonlarında yanma tarifleyen, bilateral mastektomi, kemoterapi ve radyoterapi öyküsü olan 49 yaşında bir kadın hasta, deri metastazların nadir görülen zosteriform dağılımına dikkat çekmek ve herpes zoster enfeksiyonlarının ayııı tanısında deri metastazlarını hatırlatmak amacıyla sunulmaktadır.
\end{abstract}

Anahtar Sözcükler: Deri metastazı, zosteriform deri metastazı, meme kanseri

\section{Introduction}

Cutaneous metastases from internal malignancies are rather rare, seen in only $0.7-10 \%$ of cases $(1,2)$. Breast cancer is the most common cancer in women and causes metastasis to the skin at the highest rate (1). Cutaneous metastases in breast cancer are mostly observed as rapidly developing, scattered, firm, painless, atypical papules and nodules located in the anterior thoracic wall, whereas zosteriform type cutaneous metastases are rarely encountered $(1,3-5)$. Herein, we present a 49-year-old female patient with a history of bilateral mastectomy, chemotherapy and radiotherapy who was referred to our outpatient clinic with burning, erythematous-raised papules and plaques in zosteriform distribution. Our aim was to draw attention to the fact that zosteriform distribution is rarely observed in cutaneous metastases and to remind that there are many diseases that can present with zosteriform distribution.

\section{Case}

A 49-year-old female patient was referred to our outpatient clinic due to burning rash and eruptions at the edge of the right mastectomy area spreading around that started 20 days ago. The patient was previously evaluated as herpes zoster and received systemic antiviral treatment, however, the lesions had not regressed. Her
Address for Correspondence/Yazışma Adresi: Filiz Topaloğlu Demir Şişli Training and Research Hospital, Clinic of Dermatology, İstanbul, Turkey E-mail: filizsvet@hotmail.com

Received/Geliş Tarihi: 20 March 2016 Accepted/Kabul Tarihi: 20 April 2016
${ }^{\circ}$ Copyright 2017 by The Medical Bulletin of Haseki Training and Research Hospital The Medical Bulletin of Haseki published by Galenos Yayınevi. -Telif Hakkı 2017 Haseki Eğitim ve Araştırma Hastanesi Haseki Tıp Bülteni, Galenos Yayınevi tarafından basılmıştır. 
medical history revealed, that the patient had been diagnosed with multifocal invasive ductal carcinoma in March 2013 based on the tests conducted due to a palpable mass at the upper outer quadrant of the right breast. At that time, only partial mastectomy and right axillary dissection had been performed. The patient had been given adjuvant chemotherapy and radiotherapy postoperatively. In the follow-up of the patient, nodular lesions and lymphadenopathy in the left axillary region of the right breast compatible with cutaneous metastasis had been detected in November 2014. Therefore, Taxol and platinum Gemzar treatment had been started. In the follow-ups, no regression had been observed in the lesions and therefore the patient underwent bilateral mastectomy and left lymph node dissection four months ago. In the family history, it was noted that the patient's older sister also had breast cancer. In the systemic examination of the patient, who was still receiving chemotherapy, no pathology was observed. Dermatologic examination showed that there were erythematous papules and plaques in the outer side of the right mastectomy area extending to the lateral region of the trunk and the lower parts of the posterior region of the trunk with zosteriform distribution, occasionally showing pseudovesicular appearance and fading with pressure. Laboratory tests were normal. In the histopathologic examination of the incisional biopsy from the lesion, there were large, atypical, pleomorphic, hyperchromatic cells in the dermis with vesicular nuclei and distinct nucleolus observed in lymphovascular structures and occasionally forming ductal structures and solid groups. Based on these clinical and histopathologic findings, the patient was diagnosed with zosteriform-type cutaneous metastasis of breast cancer and was referred to the oncology clinic (Figure 1,2).

\section{Discussion}

Breast cancer in women metastasizes to the skin frequently and cutaneous metastasis is observed in $23.9 \%$ of patients $(1,6)$. Although it it (cutaneous metastasis) is generally detected in patients diagnosed with breast cancer, it can be also observed as the primary finding of the malignity (6). It is most frequently observed in the anterior thoracic wall as scattered, rapidly growing, erythematous, skin-colored, firm, painless, and atypical papulonodular lesions (7). It rarely presents as erysipeloid, telangiectasia, generalized erythematous patches, neoplastic alopecia, erythema annulare centrifugum, and zosteriform distribution (1,8). Mordenti et al. (9) evaluated 164 breast cancer patients with cutaneous metastasis having an average age of 67 years. In this study, 131 patients were detected with papular and/or nodular lesions, 19 with telangiectasia carcinoma, five with erysipeloid carcinoma, five with carcinoma en cuirasse, three with neoplastic alopecia, and only one with zosteriform pattern cutaneous metastasis. They reported that the lesions were localized at the anterior thoracic wall in 75 patients. Spontaneous pain was observed in many patients with zosteriform cutaneous metastases just like in our case and most of the cases were given antiviral treatment $(2,10)$.

Skin cancers such as malignant melanoma and squamous cell carcinoma and ovarian and lung

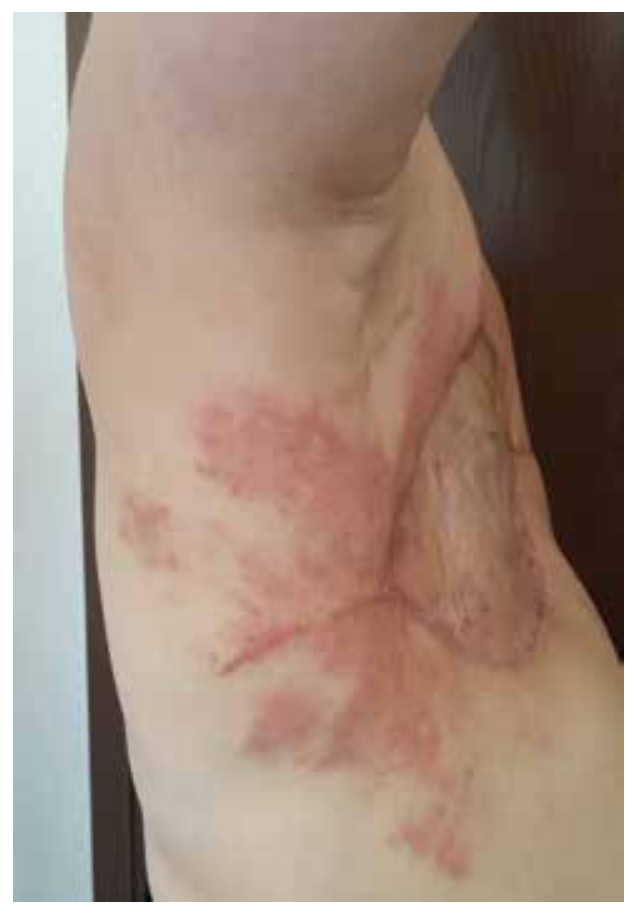

Figure 1. Erythematous papules and plaques as a zosteriform cutaneous metastasis from a breast cancer

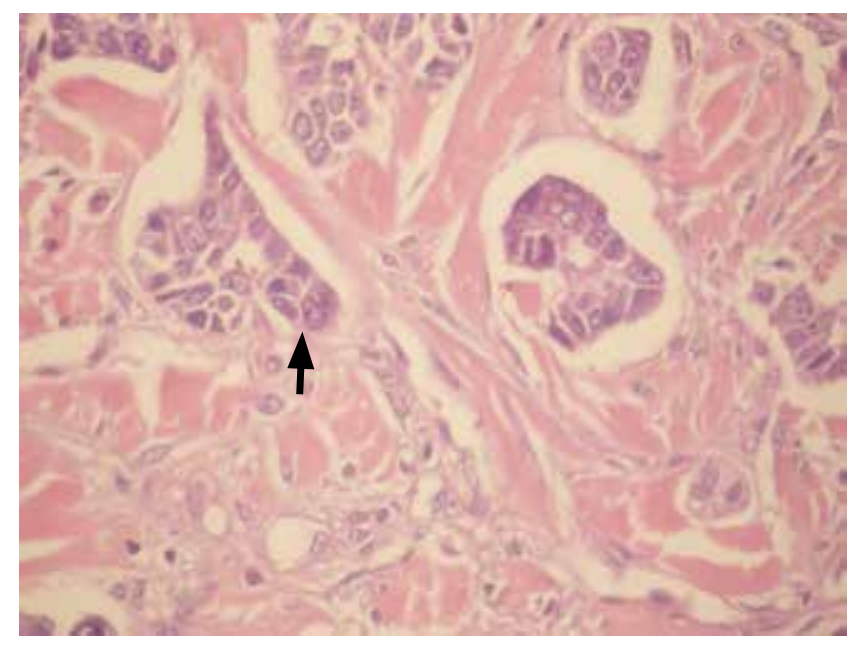

Figure 2. Large, atypical, pleomorphic, hyperchromatic cells in the dermis with vesicular nucleus and distinct nucleolus, observed in lymphovascular structures and occasionally forming ductal structures and solid groups (hematoxylin and eosin X40) 
carcinoma may also represent with zosteriform cutaneous metastases (11). The zosteriform distribution pattern may be observed in many dermatoses other than herpes zoster infection such as morphea, lichen, pityriasis rubra pilaris, spiradenoma, lentiginous nevus, papillary mucinous, and drug reactions.

There are many theories about the occurrence of zosteriform cutaneous metastasis which include occurrence due to koebnerization at the region which previously had herpes zoster infection, perineural spread, lymphatic spread, spread in dorsal root ganglion veins through fenestral route, or coincidentally during surgery $(2,10,12)$.

Although the prognosis of cutaneous metastasis depends on the type and the character of the primary tumor as well as the response to treatment, it is generally considered severe as it accompanies advance stage tumors (13). In breast cancer, cutaneous metastasis is usually evaluated as a severe prognostic factor in which life expectancy is several months, only few patients surviving for years $(7,14)$.

In conclusion, the zosteriform distribution pattern may be observed in many diseases, including herpes zoster infection, particularly. Among these diseases, cutaneous metastasis is very important as it may be the first symptom of cancer or recurrence thereof. In patients who do not show regression with antiviral treatments and demonstrate atypical morphological and distribution characteristics, cutaneous metastasis should be considered in differential diagnosis and biopsy must be performed.

\section{Ethics}

Peer-review: Externally peer-reviewed.

\section{Authorship Contributions}

Surgical and Medical Practices: Filiz Topaloğlu Demir. Concept: Filiz Topaloğlu Demir. Design: Filiz Topaloğlu Demir. Data Collection or Processing: Kenyul Salaeva, Filiz Topaloğlu Demir, Özben Yalçın. Analysis or Interpretation: Filiz Topaloğlu Demir, Illknur Kıvanç Altunay. Literature Search: Kenyul Salaeva, Filiz Topaloğlu Demir. Writing: Filiz Topaloğlu Demir, Kenyul Salaeva.

Conflict of Interest: No conflict of interest was declared by the authors.
Financial Disclosure: The authors declared that this study received no financial support.

\section{References}

1. Lookingbill DP, Spangler N, Helm KF. Cutaneous metastases in patients with metastatic carcinoma: a retrospective study of 4020 patients. J Am Acad Dermatol 1993;29:228-36.

2. LeSueur BW, Abraham RJ, DiCaudo DJ, O'Connor WJ. Zosteriform skin metastases. Int J Dermatol 2004;43:126-8.

3. Schwartz RA. Cutaneous metastatic disease. J Am Acad Dermatol 1995;33:161-82.

4. Kikuchi $Y$, Matsuyama A, Nomura K. Zosteriform metastatic skin cancer: report of three cases and review of the literature. Dermatology 2001;202: 336-8.

5. Santos-Juanes J, López-Escobar M, Villanueva Palicio N, et al. Zosteriform cutaneous metastasis from a breast carcinoma. Med Cutan Iber Lat Am 2007;35:89-93.

6. De Giorgi V, Grazzini M, Alfaioli B, et al. Cutaneous manifestations of breast carcinoma. Dermatol Ther 2010;23:581-9.

7. Zindanci I, Can B, Zemheri E, Kavala M. Two Cases of Breast Cancer Presented with Skin Metastasis as First Signs. Turkderm 2006;40:31-3.

8. Bassioukas K, Nakuci M, Dimou S, Kanellopoulou M, Alexis I. Zosteriform cutaneous metastases from breast adenocarcinoma. J Eur Acad Dermatol Venereol 2005;19:5936.

9. Mordenti C, Peris K, Fargnoli C, Cerroni L, Chimenti S. Cutaneous metastatic breast carcinoma: a study of 164 patients. Acta DermatovenAPA 2000;9:4.

10. Williams LR, Levine LJ, Kauh YC. Cutaneous malignancies mimicking herpes zoster. Int J Dermatol 1991;30:432-4.

11. Rao R, Balachandran C, Rao L. Zosteriform cutaneous metastases: a case report and brief review of literature. Indian J Dermatol Venereol Leprol 2010;76:447.

12. Atış G, Tükenmez Demirci G, Atunay Kıvanç I, Sakız D. The clinical characteristics and the frequency of metastatic cutaneous tumors among primary skin tumors. Türkderm 2013;47:166-9.

13. Schwartz RA. Histopathologic aspects of cutaneous metastatic disease. J Am Acad Dermatol 1995;33:649-57.

14. Schoenlaub P, Sarraux A, Grosshans E, Heid E, Cribier B. Survival after cutaneous metastasis: a study of 200 cases. Ann Dermatol Venéreol 2001;128:1310-5. 